\title{
ANCAMAN CAPITAL INFLOW
}

\author{
Oleh : Teguh Sihono, M.M. \\ Rohaila Yusof, Ph.D.
}

\begin{abstract}
Capital inflow can be interpreted as an increase in the amount of money available from external or foreign sources for the purchase of local capital assets such as securities, houses, buildings, land, machinery. These short-term asset purchase, so if at any time be withdrawn in large quantities, it will endanger the country's economy.

The swift flow of foreign funds may be a threat to the country which became the capital inflow in the form of options: pressure of inflation, high cost economy, the defisit Central Bank balance, the economic turbulence, and the threat of economic growth.

Improvement of high economic growth accompanied by rising foreign exchange reserves that high also, it turns out is not free from the risk of unbridled inflation and economic cricis, destabilizing the economy during those funds withdrawn by foreign investors. For the avoidance of economic risk, should the government together with the Central Bank made a rule to direct capital inflow into the real sektor.
\end{abstract}

Keywords: capital inflows, global likuiditas

\section{A. Pendahuluan}

Guncangan hebat perekonomian global yang dipicu permasalahan kredit perumahan (subprime martage) di Amerika serikat pada taun 2007/2008 lepas, ternyata masih menyisakan dampak berupa ketidak menentuan arah pemulihan perekonomian global.

Krisis yang datang silih berganti dalam perekonomian modern masa ini mengingatkan kita pada "Ponzi Ekonomi" yang dipopulerkan oleh ekonom progresif asal Amerika Serikat Hyman Minsky. Buah pikirannya sangat dipengaruhi oleh dua orang tokoh ekonomi Joseph Schumpeter dan John Maynard Keynes.

Pemikiranya, masa ini dinggap relevan oleh Wall Street setelah meledaknya kredit perumahan yang menimbulkan resesi global (Teguh S. dan Rohaila;2010). Perilaku penyelenggaraan ekonomi yang tidak hati-hati (prudent) akan berpotensi menyebabkan kegagalan (default) yang mengarah kepada krisis. Keadaan krisis mempunyai tanda-tanda awal berupa sebuah fase ketika perekonomian diwarnai ketidak mampuan membayar hutang. Ketidak mampuan membayar hutang masa ini merupakan fenomena kompleks yang saling terkait antar berbagai faktor. Krisis perekonomian di 
masa depan juga mendapatkan perhatian dari Paul Krugman sosok pemenang Nobel Ekonomi.

Membanjirnya dana investasi global ke Asia memicu fenomena ekonomi biaya mahal/tinggi. Nada optimis telah disuarakan oleh semua lapisan, atas kemilaunya proyek perkembangan perekonomian di Asia. Kita tentu masih ingat pada tahun 1990-an di mana Jepang sebagai leader barisan angsa terbang, sedangkan Indonesia kendati berada pada barisan tengah bahkan relatif di belakang telah mendapatkan sebutan sebagai "Macan Ekonomi Asia". Tetapi apa mau hendak dikata pada tahun 1997 lalu, Indonesia bersama-sama dengan Macan Ekonomi Asia lainnya luluh lantak terkena hantaman badai krisis moneter, yang kemudian berubah menjadi krisis multi dimensi yang berakibat sangat memilukan.

Masuknya dana Investor asing ke dalam negeri juga memungkinkan mendorong laju inflasi. Dengan ekonomi biaya mahal akan menekan biaya produksi meningkat, dan akan mendorong kenaikan harga barang yang diproduksikan (cost push inflation)

Derasnya laju masuknya aliran dana asing (capital inflow) yang juga lazim disebut uang panas (hot money) ke sistem keuangan suatu perekonomian akan memicu defisit pada neraca Bank Sentral, karena permintaan uang domestik meningkat, menyebabkan kerugian pada transaksi valuta asing yang dilakukan oleh Bank Sentral, dan akhirnya berimbas pada defisitnya neraca Bank Sentral.

Uang panas (capital inflow) merupakan ancaman bagi turbulensi perekonomian suatu negara. Pelaku perekonomian global pasti setuju dan mengiyakan bahwa selama tahun 2010 poros pertumbuhan ekonomi dunia bergeser ke negara-negara Asia terutama Cina dan India, kendati tidak mungkin melupakan kekuatan ekonomi tradisional Jepang. Pada periode penghujung tahun 2010 PDB beberapa negara poros ekonomi Asia melonjak mencapai angka yang cukup signifikan. Namun di tengah gelombang optimisme benua kuning ini tidak serta merta bersih dari kemungkinan gejolak dahsyat yang berujung pada krisis ekonomi baru. Di penghujung tahun 2010 Jepang akan melaksanakan kebijaksanaan fiskal agresif, dimana direncanakan pembelian aset obligasi pemerintah dan korporasi domestik dengan transaksi senilai 5 triliun yen setara US\$ 63 miliar. Sebagai tahap pertama Bank of Japan sebagai otoritas moneter mengisaratkan akan memulai program bailout dengan aktivitas pembelian obligasi pemerintah Jepang senilai 150 miliar yen. Kenyataan di lapangan menunjukkan lain, dua indikator penting yang memayungi ekonomi Jepang terlihat kepayahan. Indikator pertama berupa pertumbuhan nilai ekspor yang sudah beberapa lama stagnan, yang pada akhirnya hanya mampu mewujudkan pertumbuhan yang tipis. Malasah selanjutnya yang cukup pelik adalah negara sakura juga mulai 
secara perlahan mengalami fenomena perlambatan konsumsi domestik. Hal ini nampak pada aktivitas geliat industri manufaktur yang kini melambat pertumbuhannya.

Fenomena mulai lesunya status perekonomian beberapa negara kaya Asia dipastikan memiliki efek langsung yang secara cepat meningkatkan preferensi kekhawatiran negara-negara sekawasan terhadap resiko bisnis internasional, terutama ancaman munculnya fenomena perang dagang dan kebijaksanaan proteksi. Kebijaksanaan pertama mementingkan kebutuhan ekonomi. Kebijaksanaan yang kedua menyandarkan laju roda perekonomianya pada aktivitas konsumsi domestik. Konsekuensinya berkait dengan kemampuan negara yang bersangkutan dalam menyediakan likuiditas, baik berdenominasi domestik, dan terutama likuiditas berdenominasi asing.

Kebijaksanaan proteksionis seolah berkelahi dengan bayangan sendiri, yang setiap waktu mengancam kelangsungan masa depan perdagangan internasional. Walaupun situasi dan dan kondisi pasar ekspor pasar global terkesan tidak kondusif, akan tetapi dengan fenomena apresiasi kurs (nilai tukar) yang melanda hampir seluruh mata uang global terhadap US\$, kebijaksanaan proteksionis dapat menjadi bomerang yang mematikan. Potensi luluh lantaknya sistem perekonomian tersebut berasal dari kekeringan likuiditas, terutama denominasi US\$. Kebijaksanaan proteksionis yang agresif dapat menyebabkan suatu negara berpotensi kehilangan akses-akses strategis terhadap aliran global US\$. Jika hal ini terjadi maka kerusakan sistemik di seluruh perekonomian kawasan menjadi momok berikutnya, mulai dari collaps nya perbankan, hancurnya daya beli, hingga menggelembungnya tingkat utang negara.

Derasnya aliran dana asing (capital inflow) yang lazim disebut dengan "uang panas" dapat memicu defisit pada Bank Sentral. Capital inflow membuat permintaan akan rupiah meningkat. Imbasnya, cadangan devisa yang dibeli pada harga tinggi harus dilepas pada harga yang lebih rendah. Inilah yang akhirnya menyebabkan kerugian pada transaksi valas yang dilakukan Bank Sentral berimbas pada defisit neraca Bank Sentral (Bank Indonesia, Central Bak of Chili, Bank of Thailand).

Para ekonom memprediksikan bahwa pertumbuhan ekonomi di kawasan Asia pada tahun 2011 akan mengalami pertumbuhan yang lebih tinggi. Namun pertumbuhan yang tinggi tersebut tidak terlepas dari resiko yang lebih besar pula. Resiko dalam perekonomian itu sendiri terlihat pada semakin tingginya resiko pembalikan terhadap sektor keuangan, yang nampak peningkatan capital inflow serta kepemilikan surat utang dan saham oleh pihak asing. Perlunya mewaspadai masuknya dana asing pada instrumeninstrumen jangka pendek dapat menggoyahkan perekonomian pada saat dana tersebut ditarik keluar dalam jumlah besar. Recovery perekonomian luar 
negeri hingga kini belum menunjukkan perkembangan yang menggembirakan, dirasa sebagai penghambat pertumbuhan perekonomian domestik.

Membengkaknya defisit anggaran pada negara-negara kawasan Eropa menjadi pemicu krisis kepercayaan terhadap keadaan fiskal di negara-negara tersebut. Potensi lainnya yaitu sikap saling menyalahkan antara kubu Cina dan kubu Amerika, yang menjurus pada terjadinya perang kurs mata uang masingmasing. Beberapa hal di ataslah yang mempunyai potensi mengancam pertumbuhan perekonomian.

Namun perlu dicermati untuk tahun depan, dimungkinkan ada tiga resiko yaitu: 1) ketidak seimbangan ekonomi global yang dapat menyebabkan menurunnya permintaan eksternal terhadap ekspor dari emerging market, sementara kuatnya permintaan domestik akan mendorong akselerasi impor yang lebih tinggi. 2) Resiko capital inflow dan currency war yaitu; berlanjutnya pelonggaran moneter oleh Amerika Serikat yang akan semakin menguatkan aliran modal asing dan memberikan tekanan nilai tukar negera emerging market. 3) Jikalu respon sisi penawaran dalam perekonomian (produksi, distribusi, struktur pasar) tidak adaptatif terhadap permintaan, maka akan meningkatkan tekanan inflasi.

Oleh karena Bank Sentral setiap negara seyogianya mengambil kebijaksanaan paling tidak untuk memperkuat pengurusan likuiditas dan meningkatkan efektifitas kebijaksanaan moneter melalui penerapan kebijaksanaan moneter dan makro prodensial.

\section{B. Capital Inflow}

Capital inflow dapat diartikan sebagai peningkatan jumlah uang yang tersedia dari sumber eksternal atau asing untuk pembelian aset modal lokal seperti sekuritas, bangunan, tanah, mesin (www.ebonline,com). Arti lain modal pindah ke negara: gerakan modal ke negara dalam bentuk perdagangan efek, akuisisi perusahaan, dan pinjaman oleh perusahaan asing (http//Encarta msn com/dictionary).

Bank Dunia (World Bank) mengimbau Asia untuk mewaspadai derasnya dana asing yang masuk (capital inflow). Imbauan itu terkait dengan naiknya proyeksi pertumbuhan untuk negara-negara berkembang di Asia Timur dan Pasifik. Mereka menjelaskan, jika pertumbuhan regional ini telah kembali pulih. Pertumbuhan ekonomi kembali ke arah seperti sebelum krisis ekonomi, namun pemerintah setempat juga perlu mengendalikan risiko hot money yang masuk. World Bank menegaskan, pertumbuhan ekonomi di Asia Pasifik akan mencapai 8,9 persen pada tahun ini, naik dari perkiraan sebelumnya sebesar 7,3 persen.

"Pemulihan ekonomi di Asia Timur dan Pasifik berjalan dengan kuat. Tetapi pengelolaan resiko sekarang juga harus difokusan, karena mungkin 
akan menjadi tantangan terhadap stabilitas makroekonomi," kata World Bank dalam keterangan tertulisnya di Jakarta. Beberapa negara di kawasan itu telah melakukan intervensi di pasar valuta asing untuk memperlambat munculnya mata uang mereka, dan menimbulkan kekhawatiran dari perang mata uang yang mungkin mengganggu perdagangan dan pertumbuhan. Untuk itu, Bank Dunia meminta pemerintah negara terkait untuk bekerja dengan pendekatan ekstra. World Bank mengatakan prospek untuk Cina terlihat cerah, tetapi pemerintah Beijing harus mendorong keseimbangan perekonomiannya terkait dengan ekspor dan investasi yang masuk. Diperkirakan ekonomi Cina akan tumbuh sebesar 9,5 persen tahun ini.

"Menyeimbangkan perekonomian dengan mengubah pola pertumbuhan dan investasi menjadi hal yang penting untuk menjamin pertumbuhan, secara struktural, sosial, dan global". Laporan ini mencakup Indonesia, Malaysia, Filipina, Thailand, Kamboja, Laos, Mongolia, Myanmar, Brunei Papua Nugini, Timor Leste, Vietnam, Hong Kong, Korea Selatan, Singapura, Taiwan, Kepulauan Solomon dan negara-negara pulau kecil Pasifik.

Pemerintahan di kawasan ini dinilai perlu untuk mengatasi tajamnya kenaikan harga yang terjadi dan melindungi sistem keuangan mereka. Sementara, inflasi yang terjadi sekarang ini dinilai akibat kenaikan biaya bahan makanan dan industri. Di mana kenaikan harga di Cina dan Indonesia telah melampaui target dan Thailand diperingatkan dari bahaya yang sama.

Kawasan Asia merupakan tempat peristirahatan dana asing yang dianggap aman /nyaman, sehingga semenjak tiga tahun terakhir sektor finance mengalami surplus dana pihak ketiga. Termasuk Indonesia mencatat, sepanjang 2010 total aliran dana asing yang masuk ke Indonesia (capital inflow) mencapai US\$ 13,3 miliar.

Kasus tersebut terungkap dalam laporan hasil Operasi Pasar Terbuka (OPT) pekan terakhir Desember 2010 yang disampaikan oleh Kepala Biro Hubungan Masyarakat BI Difi Ahmad Johansyah, mengungkapkan, derasnya aliran dana asing berkait dengan optimisme pasar akan pemulihan ekonomi global di 2011. Adapun porsi kepemilikan asing di Surat Utang Negara (SUN) naik dari 29,76\% atau Rp 194,83 triliun menjadi 29,93\% atau Rp 195,75 triliun. Sementara kepemilikan asing Sertifikat Bank Indonesia (SBI) hingga akhir 2010 meningkat dari 26,95\% (Rp 53,92 triliun) menjadi 27,45\% (Rp 54,93 triliun). Sepanjang 2010, jumlah obligasi yang diterbitkan mencapai $\mathrm{Rp}$ 38,4 triliun, naik dari 2009 sebesar Rp 29,1 triliun yang didorong oleh kondisi ekonomi yang kondusif serta suku bunga yang rendah. "Emiten" didominasi oleh lembaga pembiayaan dan bank dengan porsi keduanya melebihi $50 \%$.

Pengamat ekonomi anggota Komite Ekonomi Nasional (KEN), Aviliani memperkirakan arus modal masuk (capital inflow) ke beberapa 
negara di Asia termasuk Indonesia masih akan terjadi dalam beberapa tahun ke depan. "Recovery ekonomi di AS diperkirakan baru terjadi tujuh tahun lagi sehingga dana yang ada akan mencari tempat yang memberi keuntungan. Aliran modal masuk itu harus digiring masuk ke sektor riil sehingga tidak menjadi "bubble" (gelembung) bagi perekonomian.

Pertumbuhan ekonomi yang hanya didorong oleh konsumsi tidak akan bagus, penyerapan tenaga kerja tidak ada jika tidak ada aliran modal ke sektor riil.

Untuk kepentingan ini dibutuhkan pihak-pihak berwenang untuk mendorong aliran modal masuk ke sektor riil dan tidak hanya berputar-putar saja pada sektor keuangan, baik itu di saham maupun obligasi. Maka pemerintah harus membuat aturan guna mendorong aliran modal masuk ke sektor riil. Misalnya menunda keinginan daerah menerbitkan obligasi daerah. Dampak dari derasnya capital inflow hingga saat ini adalah menguatnya nilai tukar rupiah terhadap dolar Amerika Serikat.

\section{Ancaman Capital Inflow Pada Ekonomi Biaya Mahal}

Perkembangan ekonomi dunia masa ini sangat mengkhawatirkan, Bailout baru Amerika Serikat sebagai kebijaksanaan ekonomi yang ditakuti oleh banyak negara, apalagi masa ini The Federal Reserve menetapkan rate antara $0-0,25$ persen. Hal ini yang memicu larinya modal asing ke kawasan Asia termasuk Indonesia, dan Malaysia.

Fenomena biaya ekonomi mahal.

- Diawali oleh banjir likuiditas mata uang asing yang tak terkendali

- Sistem keuangan terlalu terkonsentrasi dengan portofolio

- Persentasi Foreign Direct Investment berbanding arus dana asing yang sangat kecil

- Harga komoditas barang strategis yang semakin tinggi

- Nilai ekspor barang komoditas strategis yang semakin meningkat

- Meningkatnya korupsi, kejahatan, penyelundupan dan money laundry

- Nilai impor barang-barang konsumsi membengkak

- Pembengkakan defisit neraca perdagangan negara

- Laju inflasi tahunan yang di atas moderat

- Diakhiri dengan meningkatnya nilai uang negara secara nominal

1. Nightmare from the Flooding Liquidity (Mimpi Buruk Membanjirnya Likuiditas)

Setelah pertengan tahun 1990-an krisis keuangan melanda kawasan Asia, pada awal tahun 2000 krisis krisis seolah berkiblat di Amerika dan Eropa. Krisis perekonomian yang terjadi berturut-turut mampu merubah wajah perekonomian global secara keseluruhan. Bahkan pukulan krisis keuangan 
yang datang beruntun perkonomian global yang berkembang dalam skala ketidakpastian cenderung semakin membesar dari masa ke masa. Ketidak pastian ini nampak dari aktivitas aliran investasi dana atau likuiditas global yang seolah tak memiliki arah dan tujuan. Bahkan berdasarkan hasil dari banyak penyelidikan/riset menyatakan bahwa banyak dana investor global yang masih "menggantung di awang-awang" dan mencari tempat peristirahatan yang aman. Karena selama ini berbagai tempat yang secara tradisional menjadi lahan pengembangan dana investasi, secara struktural terancam collaps dan merusak portofolio investasi yang ada.

Krisis mortgage Amerika kemudian dilanjutkan dengan krisis utang Dubai world, gejolak fiskal negara-negara minor Eropa berlanjut menjadi ancaman meluasnya buble's surat utang perbankan, yang masa ini terjadi kerancuan sosial-ekonomi negara-negara yang secara tradisional telah lama menjadi tulang punggung perekonomian benua Eropa. Karena itu, para investor global "mereposisi" porsi portofolio investasinya dan mencari lahan investasi baru.

Melihat kondisi likuiditas global yang mungkin mengalami "rabun mata" merupakan peluang bagi negara-negara yang memiliki resiko investasi rendah. Tetapi jika di cermati lebih dalam, ancaman banjir likuiditas ternyata menyimpan "tsunami" perekonomian yang amat dahsyat.

2. The Story Begins (Awal Ceritera)

Likuiditas global datang ke sistem perekonomian suatu negara dengan membawa keunggulan nilai tukar yang dimiliki oleh denominasi mata uangnya. Dengan keunggulan ini mampu memberikan keunggulan kompetitif dalam sistem perdagangan internasional. Keunggulan nilai tukar sangat menarik minat perusahaan dan badan usaha milik negara di negara tersebut untuk menjual barang-barang yang dimiliki. Hal ini tidak karena nilai keuntungan dala mata uang domestik sahaja, tetapi juga karena konsekuensi semakin meningkatnya kebutuhan banyak entitas ekonomi di negara mereka terhadap mata uang asing tersebut. Dirasa memiliki keunggulan nilai tukar, maka dimanfaatkan untuk mengincar barang-barang yang memiliki nilai strategis di negara yang kurs nilai mata uangnya lebih lemah. Transaksi jualbeli akan menjadi masalah jikalu akibat dari transaksi menimbulkan kelangkaan pasokan pada barang-barang yang tergolong vital bagi masyarakat negara yang bersangkutan. Kelangkaan pasokan ini akan memberikan efek kenaikan harga terhadap barang-barang dan jasa. Kenaikan harga barangbarang kebutuhan primer mendorong harga bahan baku industri ikut melambung tinggi, dan kemudian baru diikuti dengan langkah-langkah efisiensi.

Pihak otoritas negara niscaya akan mengeluarkan kebijaksanaan pembatasan aktivitas transaksi jual-beli komoditas primer ke pasar yang 
menggunakan mata uang asing dan memprioritaskan kembali bagi pemenuhan konsumsi dalam negeri. Pembatasan aktivitas transaksi komoditas primer akan menimbulkan pasar gelap untuk komoditas tersebut. Untuk menjaga eksistensi bisnis tersebut pemain pasar harus menyuap aparat pemerintah yang bertanggung jawab dalam pengawasan.

3. Well Come Aboard The Great "Investment" (Selamat Datang Kapal Besar Investasi)

Banyaknya uang panas yang beredar dalam sistem perekonomian sebenarnya tidak menguntungkan bagi pertumbuhan kekayaan negara, karena uang yang diperoleh dari nihilnya peningkatan produktivitas kelak akan mengalir kembali keluar negara. Karena tidak mungkin uang tersebut akan diinvestasikan melalui paper investment apalagi riil investment di negara yang bersangkutan. Aliran uang panas tersebut mudah dideteksi lewat lembaga perbankan atau lewat pembelian barang-barang mewah yang akan dijual lagi maupun yang akan dipergunakan untuk konsumsi bagi kalangan terbatas. Jika alternatif yang kedua (pembelian barang sekunder dan tersier) meningkat, maka berakibat menurunnya penjualan barang-barang sejenis di dalam negeri. Para produsen akan merespon dengan mengurangi skala produksinya. Penurunan skala produksi ini akan meluas ke seluruh produksi barang komplementer dan barang subtitusi yang ditinggalkan konsumen.

Dengan aliran likuiditas global yang terus berdatangan, dan fenomena penurunan produksi barang secara nasional akan mendorong laju inflasi. Inflasi ini merupakan pukulan bagi masyarakat yang berpenghasilan tetap. Para pejabat dan birokrat pemerintah negara mengalami nasib sama. Dengan kekuasaan atas semua urusan administrasi dan hukum negara, secara perlahan peran sentral para abdi negara mengalami "revitalisasi". Yang semula bertujuan melayani dan mempermudah semua semua kegiatan perekonomian, berubah menjadi tumpukan labirin (labyrinth) penghalang yang memiliki konsekuensi biaya. Maka ekonomi biaya mahal akan merajalela. Guna memerangi ekonomi biaya mahal, pemerintah tak punya pilihan lain, selain meningkatkan gaji pejabat dan jajaran birokrat.

4. No More for The Cheaper (Tidak Ada Lagi Murah)

Untuk mencegah ekonomi biaya mahal pemerintah dapat melakukan kebijaksanaan menaikkan gaji pegawai dan jajaran birokrat. Harapan kebijaksanaan ini untuk memberantas kebiasaan para birokrat menerima suap yang menimbulkan sumbatan ekonomi dan munculnya fenomena ekonomi biaya mahal. Dengan semakin menurunnya out-put nasional, negara mulai berfikir untuk mendapatkan sumber pendapatan yang lain. Pertama, memperbesar pendapatan dari pajak, dengan kebijaksanaan fiskal agresif yaitu menaikkan tariff pajak yang sudah ada, menambah jenis pajak baru, maupun memperluas basis warga negara yang penghasilannya terkena pajak. 
Penghasilan dan daya beli terus menerus tergerus oleh infasi , kebijaksanaan pajak yang dilakukan negara secara masif (kukuh) akan menambah beban hidup rakyat. Tingkatan kebutuhan yang semakin tinggi, sebagai makhluk ekonomi mereka akan mencari cara agar pendapatan mereka tidak tergerus inflasi dan berbagai kewajiban. Kehidupan rakyat akan dilandasi dan berorientasi pada "untung rugi" secara nominal, kesenjangan semakin lebar, kriminalitas semakin merajalela.

Ekonomi biaya mahal akan tetap bertahan, disebabkan para aparat dan birokrat dalam memberikan pelayanan menghalalkan segala cara untuk mempertahankan standar hidupnya. Para pelaku usaha untuk mempertahankan laba, mereka menggunakan cara termudah yaitu menaikkan harga barang produksinya. Opsi yang memungkinkan dilaksanakan oleh negara, jikalau pos pendapatan pajak tidak mampu menghilangkan defisit anggaran negara yaitu: a) penerbitan surat utang negara (SUN), b) melakukan penjualan produk hasil badan usaha, c) melakukan penjualan hak kepemilikan perusahaan. Semua opsi kebijaksanaan yang diambil mempunyai konsekuensi menaikkan biaya perekonomian.

\section{Ancaman Capital Inflow Pada Laju Inflasi}

Berbicara tentang ekonomi makro, pertumbuhan ekonomi masih menjadi fokus perhatian semua negara di dunia, Berbagai strategi dilakukan dalam usaha meningkatkan pertumbuhan Gross Domestik Product (GDP) atau Pendapatan Domestik Bruto (PDB) Negara. Tetapi peran inflasi sering diabaikan, padahal jikalau laju inflasi tidak dapat dikendalikan akan menbahayakan perekonomian negara yang bersangkutan.

Inflasi dikenal ada dua tipe yaitu inflasi karena tarikan permintaan atauFull Demand Inflation dan inflasi karena desakan biaya atau Cost Push Inflation (Boediono. Dan Nopirin). Inflasi pertama lebih cenderung disebabkan karena pertambahan jumlah uang beredar. Jenis pertama ini relatif mudah dikendalikan, sedangkan jenis yang kedua cost push inflation relatif sulit di atasi. Inflasi di Indonesia selama bulan januari - Nopember tahun 2010 mencapai 5,98\% sedangkan pertumbuhan ekonomi sampai akhir tahun 2010 diprediksikan $6,3 \%$.

Menyimak proses ekonomi biaya mahal, maka inflasi yang terjadi sebagai akibat uang panas (capital inflow) adalah cost push inflation, di mana naik harga barang-barang yang disebabkan kenaikan biaya produksi. Untuk mempertahankan tingkat keuntungan para produsen menaikkan harga barangbarang yang diproduksi. Inflasi, seperti paparan di atas, merupakan pukulan bagi setiap warga negara yang berpenghasilan tetap. Akan tetapi jikalau warga negara menuntut perbaikan pendapatannya, hal inipun juga akan menyebabkan kenaikan biaya produksi, dan produsen juga akan menaikkan 
harga barang-barang yang diproduksikan untuk mempertahankan keuntungnnya, maka akan timbul siklus inflasi baru.

Dengan Mengambil tingkat inflasi di Indonesia pada tahun 2010 sebesar $5,98 \%$ sementara pertumbuhan ekonomi pada tahun 2010 sebesar 6,3\%, maka persentase tingkat inflasi yang mendekati persentase pertumbuhan ekonomi, menunjukkan sangat tipisnya angka pertumbuhan ekonomi riil nasional.

\section{E. Ancaman Capital Inflow Pada Defisit Bank Sentral}

Besarnya laju capital inflow, juteru mempebesar difisit neraca bank Sentral, seperti yang di alami oleh Central Bank Of Chilie, Central Bank Of Thailand, dan Bank sentral Indonesia. Bank Indonesia sampai akhir tahun 2010 mengalami defisit sebesar Rp 37 Triliun dan diprediksikan untuk tahun 2011 sebesar Rp 49 triliun.

The Federal Reserve dengan kebijaksanaan Bailout kepada pemerintah Amerika Serikat menjadi pemicu membanjirnya dana asing (capital inflow), disamping Rate of interest The Fed yang dipatok antara 0 0,25\%. Jika kita bandingkan dengan Indonesia rate BI: 6,5\%, Malaysia: 2,75\%, Singapura: 0,5\%, Thailand: $2,25 \%$ dan Philipina: $4 \%$

Dana likuid tersebut wajar kiranya akan mencari tempat yang aman/nyaman dan sekaligus memberikan margin, yaitu di kawasan Asia.

Bailout dalam istilah ekonomi dan keuangan digunakan untuk menjelaskan situasi dimana sebuah entitas yang bangkrut atau hampir bangkrut, seperti perusahaan atau sebuah bank diberikan suatu injeksi dana segar yang likuid, dalam rangka untuk memenuhi kewajiban jangka pendek. Seringkali bailout dilakukan oleh pihak pemerintah atau konsorsium beberapa investor yang akan meminta peran kendali pada entitas tersebut sebagai timbal balik untuk dana yang disuntikkan.

Umumnya, bailout adalah respon terhadap adanya kesulitan pada aliran dana jangka pendek, dimana entitas yang mengalami kesulitan dana likuid namun memiliki asset yang cukup, akan disuntik dana oleh pemerintah atau konsorsium investor untuk "tide it over" hingga masalah keuangan jangka pendek dapat diselesaikan.

Defisit neraca Bank Sentral pada dasarnya tidak mengkhawatirkan, mengingat tidak akan berpengaruh pada pertumbuhan perekonomian bagi negara yang bersangkutan dan dapat diatasi dengan mencetak mata uang baru. Cadangan devisa yang dimiliki suatu negara yang masa ini relatif besar (Indonesia US\$ 96,207 Miliar) tidak dapat digunakan untuk membiayan investasi di dalam negeri. Sehingga diharapkan pemerintah mempunyai kebijaksanaan yang mampu mereposisi aliran uang panas ke sektor riil, maka suatu keniscayaan perekonomian akan tumbuh lebih pesat dan mampu meningkatkan produktivitas nasional. 


\section{F. Ancaman Capital Inflow Pada Turbulensi Ekonomi}

Berlatar belakang kebijaksanaan "bailout" yang digulirkan Amerika Serikat, dan mulai merebaknya berita kerapuhan struktur perekonomian negara-negara anggota Uni Eropa nampaknya cukup beralasan. Guna meredam inflasi domestik beberapa negara di kawasan Asia Fasifik mulai menaikkan suku bunga kredit.

Selama tahun 2010 poros pertumbuhan ekonomi dunia mulai bergeser ke negara-negara Asia, terutama Cina dan India. Proses pertumbuhan ekonomi Asia diyakini oleh pelaku perekonomian global, karena beberapa indikator perekonomian di negara-negara tersEbut menunjukkan angka kenaikan disertai dengan pembukuan nilai yang cukup signifikan. Indikator yang menunjukkan validitas pertumbuhan yaitu semakin membaiknya angka indeks manufaktur dan tingkat permintaan pasar. Maka tak mengherankan jika di ujung tahun 2010 Pendapatan Domestik Bruto (PDB) negara-negara poros ekonomi Asia naik mencapai angka yang sigmifikan.

Akan tetapi ditengah gelombang optimisme yang melanda dunia kuning, ternyata tidak serta-merta bebas dari gejolak dahsyat yang berujung pada krisis ekonomi baru. Bank Sentral Jepang juga akan melakukan kebijaksanaan fiskal agresif, dengan melakukan pembelian obligasi pemerintah dan korporasi domestik yang mencapai nilai 5 triliun yen (US\$ 63 miliar). Program bailout ini diawali dengan pembelian obligasi pemerintah senilai 150 miliar yen, dengan alasan perekonomian Jepang sudah mulai menggeliat. Padahal kenyataan di lapangan membuktikan lain, dua indikator penting yang menjadi tolok ukur perekonomian Jepang mengalami kepayahan. Indikator pertama yaitu pertumbuhan nilai ekspor yang sedang stagnan, dan indikator yang kedua perlambatan konsumsi domestik. Kedua indikator tersebut nampak pada aktivitas industri manufaktur yang pertumbuhannya melambat, pemangkasan produksi sudah dilakukan lima kali berturut-turut, sedang dari sisi margin semenjak tahun 2009 saat ini terendah.

Lesunya perekonomian beberapa negara kaya di Asia memiliki efek langsung yang secara cepat meningkatkan preferensi kekhawatiran negaranegara sekawasan Asia terhadap resiko bisnis internasional. Sesuatu yang logis manakala kondisi pasar global terimbas gejolak pasar modalnya, kebijaksanaan mementingkan kebutuhan ekonomi masing-masing negara sebagai kebijaksanaan utama yang mesti dilakukan. Ditengah pasar internasional yang lesu, maka dapat dipastikan setiap negara akan menyandarkan perekonomiannya pada aktivitas konsumsi domestik. Walaupun disadari bahwa langkah inipun menuntut konsekuensi yang berkait dengan kemampuan negara dalam menyediakan likuiditas, yang berdenominasi domestik dan terutama denominasi asing. 
Kebijaksanaan proteksionis seolah berkelahi dengan bayangan sendiri, yang setiap waktu mengancam kelangsungan masa depan perdagangan internasional. Walaupun situasi dan dan kondisi pasar ekspor pasar global terkesan tidak kondusif, akan tetapi dengan fenomena apresiasi kurs (nilai tukar) yang melanda hampir seluruh mata uang global terhadap US\$, kebijaksanaan proteksionis dapat menjadi bumerang yang mematikan. Potensi luluh lantaknya sistem perekonomian tersebut berasal dari kekeringan likuiditas, terutama denominasi US\$. Kebijaksanaan proteksionis yang agresif dapat menyebabkan suatu negara berpotensi kehilangan akses-akses strategis terhadap aliran global US\$. Jika hal ini terjadi maka kerusakan sistemik di seluruh perekonomian kawasan menjadi momok berikutnya, mulai dari collaps nya perbankan, hancurnya daya beli, hingga menggelembungnya tingkat utang negara.

Gambaran yang dapat menjadi contoh misalnya; di Jepang terjadi penurunan tingkat konsumsi masyarakat yang menjadi pekerjaan rumah yang amat rumit bagi Perdana Menteri Naoto Kan. Di Amerika indeks konsumsi turun dari 96 menjadi 26. Sehingga alternatif kebijaksanaan yang kedua pemerintah Jepang untuk menghadapi badai krisis keuangan yang memiliki magnitude yang sangat mengancam pupus sudah.

Lonceng kewaspadaan Perekonomian Asia meliputi; 1) kebijaksanaan fiskal agresif, 2) ancaman aktivitas perekonomian pada perdagangan internasional, 3) naiknya biaya modal dan suku bunga kredit Asia, 4) meningkatnya arus perdagangan pisik atau kontrak derivatif emas, 5) peningkatan nilai pencadangan sistem perbankan, 6) peningkatan nilai cadangan devisa negara-negara Asia, 7) inflasi mulai merangkak naik, 8) melonjaknya harga komoditi energi internasional, 9) melonjaknya harga bahan pangan, 10) maraknya kejahatan korupsi dan money laundry atau pencucian uang.

\section{G. Ancaman Capital Inflow Pada Pertumbuhan Ekonomi}

Pada tahun 2011 pertumbuhan ekonomi di Asia termasuk Indonesia diprediksikan lebih tinggi, namun pertumbuhan ini tidak terlepas dari resikoresiko yang lebih besar pula. Resiko ini nampak pada makin tingginya resiko pembalikan terhadap sektor keuangan, yaitu capital inflow dalam satu tahun terakhir mengalami peningkatan, serta kepemilikan surat utang dan saham oleh pihak asing sebesar Rp 119,5 triliun. Masuknya dana asing ke dalam suatu perekonomian dapat menggambarkan bahwa perekonomian di negara tersebut di mata investor asing mempunyai prospek yang baik/ menggembirakan. Namun jika masuknya dana asing ke dalam instrumen jangka pendek perlu diwaspadai, karena jika sewaktu waktu dana tersebut ditarik, dapat menggoncangkan perekonomian, apalagi dalam jumlah besar. 
Ancaman capital outflow membutuhkan perhatian pemerintah guna menerapkan kebijaksanaan yang lebih mengikat atau dana-dana tersebut dapat disalurkan ke sektor riil yang membutuhkan untuk mengembangkan usahanya.

Resiko recovery perekonomian luar negeri yang sampai masa ini belum menunjukkan perkembangan yang menggembirakan juga merupakan potensi yang menghambat pertumbuhan ekonomi domestik. Masih membengkaknya defisit anggaran pada negara-negara kawasan Eropa menjadi pemicu krisis kepercayaan terhadap keadaan fiskal negara-negara kawasan tersebut. Potensi lain misalnya adanya perang kurs antara Cina dengan Amerika Serikat. Pihak Amerika serikat menaruh kecurigaan yang kuat terkait dengan Beijing yang membiarkan nilai kurs Yuan tetap tertekan demi keuntungan perdagangan internasional. Namun Cina menyatakan hal sebaliknya, bahwa kerugian Amerika Serikat di dalam perdagangan internasional lebih dikarenakan tidak adanya kebijaksanaan yang mendukung bagi perdagangan mereka sendiri.

\section{H. Kesimpulan}

Pemulihan krisis finansiil di Amerika Serikat yang terjadi pada tahun 2007/2008 membutuhkan waktu tujuh tahun lagi. Akibat dari krisis finansiil dan kebijaksanaan bailout bagi kawasan Asia menjadi tujuan aliran dana asing yang kemudian masuk pada sistem perekonomian negara-negara Asia untuk pembelian sekuritas/efek.

Masuknya dana asing (uang panas) ke perekonomian negara-negara Asia mempunyai efek logis seperti; ekonomi biaya tinggi, menekan laju inflasi, defisit neraca Bank Sentral, turbulensi ekonomi, dan bencana bagi pertumbuhan ekonomi.

Membanjirnya capital inflow, menaikkan kurs nilai tukar yang akan mendorong transaksi jual-beli dan kemudian menaikkan harga barang dan jasa. Likuiditas global akan menambah jumlah uang beredar dalam masyarakat yang kemudian juga akan terjadi tekanan inflasi. Tekanan inflasi inilah yang memukul masyarakat yang berpenghasilan tetap, maka mereka berusaha mencari penghasilan tambahan. Defisit Anggaran Pendapatan dan Belanja, negara mencari alternatif peningkatan pendapatan dengan: kebijaksanaan fiskal agresif, menerbitkan surat berharga, penjualan barangbarang yang dihasilkan, bahkan penjualan hak kepemilikan negara atas perusahaan. Semua dilakukan untuk menghadapi inflasi, tetapi berakibat melanggengkan biaya ekonomi mahal.

Likuditas global dapat berakibat pada defisit neraca Bank Sentral, karena harus menjual cadangan devisa dengan harga yang relatif rendah, dibanding masa pembelian devisa yang tinggi. Hal ini dikarenakan 
melimpahnya dana asing untuk keperluan transaksi pembelian sekuritas perusahaan domestik.

Pertumbuhan ekonomi di poros ekonomi Asia, tak bebas dari gejolak yang dahsyat, sebab pertumbuhan tersebut akan berujung pada krisis ekonomi baru. Likuiditas global merupakan ancaman gejolak (turbulence) ekonomi Asia. Jepang ternyata juga mengalami kelesuhan produksi manufaktur (turunnya nilai ekspor dan tingkat konsumsi masyarakat), sehingga Bank of Japan melakukan bailout .

Alternatif kebijaksanaan ekonomi yang bertumpu pada konsumsi domestik menuntut konsekuensi negara untuk menyediakan likuidtas yang berdenominasi domestik maupun likuiditas yang berdenominasi asing. Resiko pembalikan sektor keuangan merupakan potensi pertumbuhan yang terancam bencana. Hal ini dapat terjadi sewaktu para investor asing menarik dana jangka pendek secara mendadak dalam jumlah besar.

\section{Daftar Pustaka}

Ahmad Zaki Matsir. Uang Panas Memicu Defisit Bank Sentral. Warta Ekonomi. 23 Desember-28 Desember 2010, Jakarta.

Andreas Timothy. Selasa 19 Oktober 2010. Menghimbau Negara-Negara Asia Timur Mewaspadai Derasnya Lalu Lintas Dana Asing Yang Masuk, Jakarta-Micom.

Aviliani. 03 Mart 2010. Aliran Dana Bailout Penting Diungkap. Mata News Com.

Brahmanian. Ekonomi Amerika Serikat Belum Pulih. Warta Ekonomi 27

April -2 Mei 2009, Jakarta.

Boediono.1980. Teori Moneter Edisi ke 2. BPFE-UGM, Yogyakarta

Budi Sudjijono. 2008. Resesi Dunia dan Ekonomi Indonesia. Golden Terayon Press, Jakarta

Difi Ahmad Johansyah. Kekhawatiran Capital Inflow dan Currency War. Vibiz Com. 01 Desember 2010. Jakarta.

Estey James Arthur. 1960. Business Cycles, Their Nature, Cause, and Control.Third Edition. Prentice Hall, Inc.Englewood Cliffs - USA.

Hansen H. Alvin. 1951, Business Cycles and National Income. W.W. Norton \& Company, Inc. New York. http.//Encarta msn com/dictionary

Khor, Martin. 2008. The Malaysian Experience in Financial-Economis Crisis Management : Alternative to The IMF-Style Approach. Third World Network (TWN) Penang-Malaysia.

Meier Gerald M. dan R.E. Baldwin. 1957. Economic Developedment. John Wiley \& Sons Inc. New York, New York. 
M. Suparmoko. 2003. Keuangan Negara Dalam Teori dan Praktik. BPFEUGM Edisi ke-5, Yogyakarta.

Nopirin. 1987. Ekonomi Moneter Buku II Edisi 1. BPFE-UGM, Yogyakarta.

Rangga Lesmana. Ancaman Turbulensi Ekonomi Asia-Fasifik. Warta Ekonomi 23 Desember-26 Desember 2010, Jakarta

Sriwijaya Post. Kamis 15 Juli 2010. Pemerintah waspadai aliran dana asing: Agus Martowardoyo (Menteri Keuangan RI)

Suryo Saputro. Tiga Risiko Ekonomi Global. Warta Ekonomi. 13 Desember28 Desember 2007, Jakarta.

Teguh Sihono dan Rohaila Yusof. 2010. Impact of Crisis Financial United Stated Toward Asia Economic. Journal FPE-UPSI Tanjungmalim 2010, Malaysia.www.businessdictionary com. 